\title{
A mineralogical study of Late Bronze Age ceramics from Palatca (Transylvania, Romania)
}

\section{Lucretia GHERGARI \& Carmen STÂNCEL}

\author{
Department of Geology, “Babeş-Bolyai” University, Kogălniceanu 1, 400084 Cluj-Napoca, Romania
}

Received August 2011; accepted January 2012

Available online 8 January 2012

DOI: $10.5038 / 1937-8602.57 .1 .2$

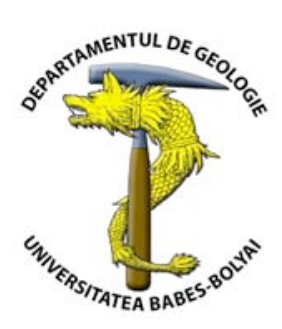

\begin{abstract}
Our paper studies the mineralogical and petrographical characteristics of 28 ceramic fragments that were excavated in the village of Palatca, Transylvania (Romania). Optical microscopy, X-Ray powder diffraction (XRD), scanning electron microscopy (SEM), grain size analyses, and porosity measurements were used to investigate the samples. Our objective was to describe or reconstruct the corresponding products and to elucidate the manufacturing process, the firing techniques, and the transformation pathways. Based on our results, we conclude that the Late Bronze Age ceramics (1600-1300 BC) were produced from clay and temper material such as river sand and ceramoclasts. It has been modeled by hand and fired between 800 and $950^{\circ} \mathrm{C}$. For most samples, we can narrow the temperature range to $850-900^{\circ} \mathrm{C}$. We interpret the data further from a geoarchaeological point of view with respect to the historical
\end{abstract} evolution of the local culture.

Key words: Bronze Age ceramics, geoarchaeology, mineralogy, firing temperature, Palatca, Romania.

\section{INTRODUCTION}

The area of research that combines archaeology, geology, and mineralogy is known as geoarchaeology and archaeometry. Revealing the necessity of an interdisciplinary approach in ancient ceramics research, Maggetti (2006) shows that "This area of research, in which these disciplines overlap, is known as archaeometry or archaeological sciences". Ceramics are some of the most analytically relevant artifacts unearthed from archaeological sites because they provide information on technologies and styles used. Moreover, ceramics can be easily associated with specific (prehistoric) periods and cultures. Thus, mineralogical studies on ancient ceramics have become an efficient way for identifying processing techniques from raw material to the final ceramic objects that were used by ancient populations (e.g., Shepard, 1976; Rapp and Hill, 1998; Maggetti, 2006).

Here, we discuss the results of our study on the mineralogical and petrographical characteristics of 28 ceramic fragments recovered from a Late Bronze Age (1600-1300 BC) site located in Palatca village, east of ClujNapoca, Romania. Our main goals were to define the manufacturing technologies and to identify the sources of raw materials.

\section{ARCHEOLOGICAL AND GEOLOGICAL BACKGROUND}

The ceramic materials are mainly fragments of common vessels that were probably meant for domestic usage. The samples show various colors ranging from dark-red and brown to black. Some are decorated with imprints in different styles that are characteristic for the Wittenberg, Otomani, Noua, and Bădeni III-Deva cultures (Fig. 1; Rotea, 1997).

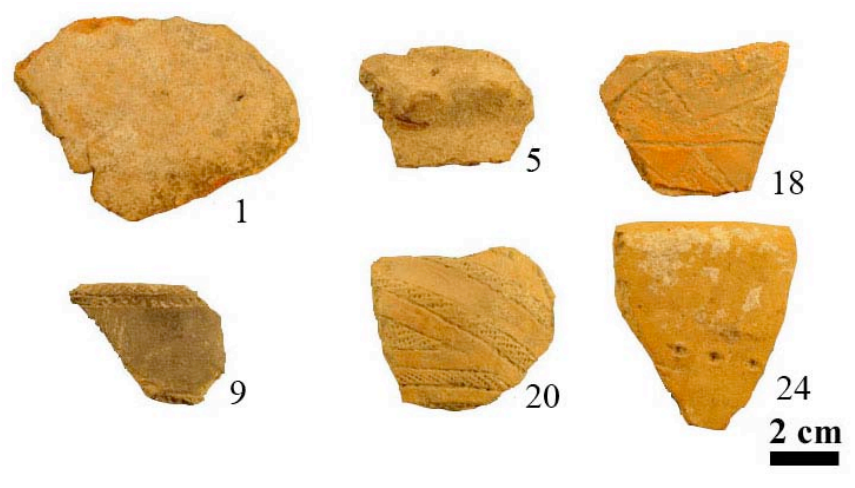

Fig. 2. Ceramic fragments from Palatca, outside views.

From a geological point of view, the Palatca site is hosted within the sedimentary formations of the Transylvanian Basin. The geological map in Fig. 2 shows the site location and indicates the presence of Miocene and Quaternary deposits. The Miocene sequence is represented by calcareous clays, sandstones, sands, salt diapirs, and volcanic tuffs of Badenian age (the Borşa-Apahida horizon of dacitic composition), as well as marls, sands, pebbles, and two horizons (Hădăreni, dacitic and Ghiriş, andesitic) of Sarmatian volcanic tuffs (Filipescu, 1996). The Quaternary consists of Pleistocene terraces and Holocene alluvia with sands and pebbles (Saulea et al., 1968). 


\section{SAMPLES AND ANALYTICAL TECHNIQUES}

The sample material has been geoarchaeologically investigated by Precup (2008) and Hoeck et al. (2009). For our present study, we have selected and labeled 28 samples from the ceramic material. The "Togul lui Mândruşcă" excavation site (code "37"; Rotea, 1997) is located in Palatca commune, which is located $36 \mathrm{~km}$ east of ClujNapoca, Romania (Fig. 2).

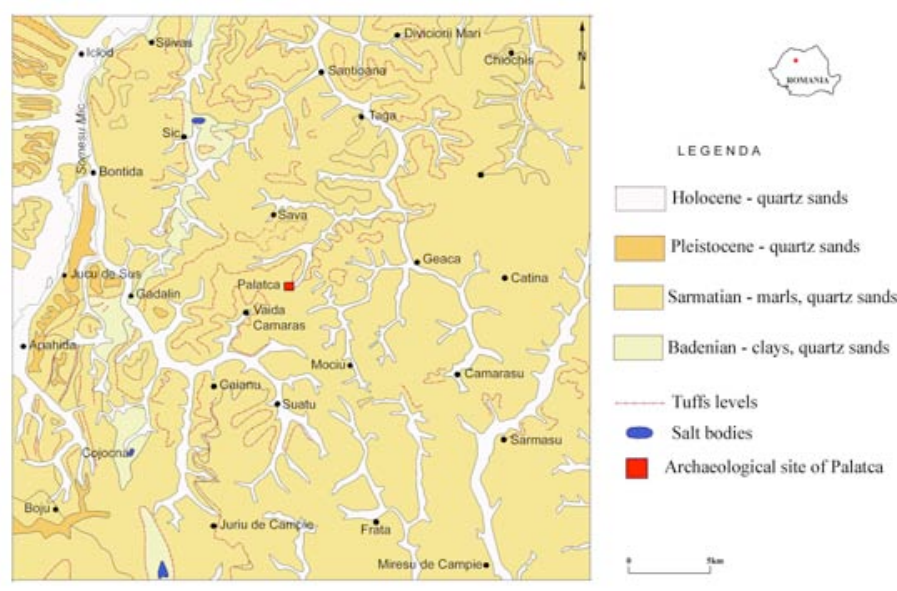

Fig. 1. Geological sketch with the location of the archaeological Palatca site (up right corner) on the map of Romania. Redrawn after Marinescu and Peltz (1967); Saulea et al. (1968); Geological map of Romania, Scale 1:200.000, Bistrita and Cluj sheets.

For our optical study and grain size analyses, we used a Nikon SMZ660 stereoscopic microscope and a Nikon Elipse E200 Pol microscope equipped with a COOLPIX 995 digital camera and a point-counter device. In addition, we generated high resolution images using a Leica Stereoscan 430 scanning electron microscope (SEM) operated at $10 \mathrm{kV}$, both, in normal and backscattered mode. The porosity measurements were made on a Mettler Toledo CB 203 digital balance. X-ray powder diffraction analyses were conducted by using a DRON3 instrument $(20 \mathrm{kV}, 20 \mathrm{~mA}$, continuous scans from $2^{\circ}$ to $64^{\circ} 2 \theta$; scan speed $2^{\circ} \theta$ /minute; $\lambda_{\mathrm{K} \alpha}=1.54051 \AA$ ).

\section{RESULTS AND DISCUSSIONS}

Macroscopic observations on both ceramic walls indicated that the fragments display homogeneous colors. The thickness of the wall varies between 4 and $20 \mathrm{~mm}$. A visual examination of cross-sections revealed that the yellowish, reddish, or black colors are homogeneously or randomly distributed throughout the ceramic body. Some samples, i.e., 4, 20, 21, and 22, display a layered texture characterized by dark colored cores and distinctive reddish rims (Fig. 3a). This texture is probably caused by changes of the oxidative-reductive conditions. The ceramics are coarse to semi-fine grained (Fig. 3a, b), and contain (sub-)angular and sub-rounded inclusions of different sizes $(<4 \mathrm{~mm} \emptyset)$. The porosity consists of voids and channels at the millimeter and sub-millimeter scale.

\section{Mineralogy and petrography of Palatca ceramics}

We identified the fabric, mineralogy, and petrography of the ceramic components by using polarized microscopy and thin sections.

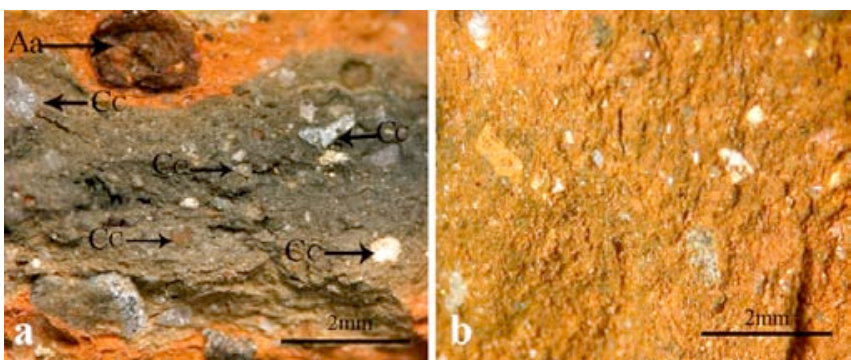

Fig. 3. a) Coarse ceramic showing a layered structure. Ferruginous clay aggregates (Aa), clasts (Cc) (Sample 20).

b) Semi-fine ceramics; ceramoclasts, and small lithoclasts in a poorly oriented, porous matrix (Sample 18).

The fabric illustrates the way the product was obtained (Moody et al., 2003). Fabrics are defined by the ceramic structure, i.e., the particle size distribution, the apparent porosity, and the ceramic texture, i.e., the orientation of elongated elements (Ionescu and Ghergari, 2007). In addition, the microstructure of the matrix indicates the degree of the thermal transformation.

The grain-size distribution was obtained by using the linearly-integrated planimetric method (Járai et al., 1997). We have determined the surfaces occupied by: the matrix, the pores and 4 grain categories (Wentworth, 1922): clay (lutite; $<0.004 \mathrm{~mm})$, silt $(0.004-0.063 \mathrm{~mm})$, sand (arenite; $0.063-2.0 \mathrm{~mm}$ ), and pebbles (rudite; $>2.0 \mathrm{~mm}$ ). The results are given in Table 1, and one can observe that in average lutite represents $55.92 \%$, silt $29.42 \%$, and arenite $13.60 \%$, respectively. Just $1.17 \%$ of all studied ceramic fragments are represented by rudites. Ghergari et al. (1999, 2000) suggested using the classical sedimentological grain-size classes and ternary projections for ceramics. The ternary diagram of the grain-size distribution in Palatca ceramics (Fig. 4) is based on the graphical representation of fineness classes (Ionescu and Ghergari, 2002).

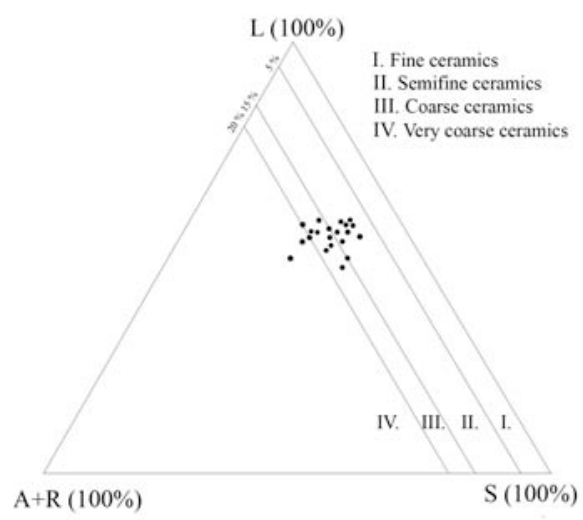

Fig. 4. Ternary diagram projection of the grain size measurements for the Palatca ceramics.

Ceramics can be classified as fine, semi-fine, medium, coarse, and very coarse (Fig. 4) grained based on the grain size data grouped in intervals limited by 5,15 , and $20 \%$ arenite+rudite. $57 \%$ of the studied ceramic fragments plot in the semi-fine field, i.e., samples 4, 6-10, 14, 16, 18, 20-24, 27 , and 28 . This category is characterized by $50-62 \%$ lutite, $28-35 \%$ silt, $8-5 \%$ arenite, and $0-2 \%$ rudite content. The coarse category represents $36 \%$ from all studied samples (i.e., $1,5,11-13,15,17,19,25$, and 26). In this case, lutite represents $48-59 \%$, silt $25-35 \%$, arenite $8-20 \%$, and rudite 0 $6 \%$. Just $7 \%$ of all samples belong to the very coarse category 
Table 1. Grain size analyses of Palatca ceramics.

\begin{tabular}{|c|c|c|c|c|c|c|c|c|}
\hline \multirow{2}{*}{$\begin{array}{c}\text { Sample } \\
\text { No. }\end{array}$} & \multicolumn{4}{|c|}{ Granulometric categories [\%] } & \multirow{2}{*}{$\begin{array}{c}\Phi^{*} \\
\max . \\
{[\mathrm{mm}]}\end{array}$} & \multicolumn{2}{|c|}{ Arenite \& rudite composition } & \multirow{2}{*}{$\begin{array}{l}\text { Granulometric } \\
\text { category }\end{array}$} \\
\hline & Lutite & Silt & Arenite & Rudite & & $\begin{array}{l}\text { Litho- and } \\
\text { crystalloclasts }\end{array}$ & Ceramoclasts & \\
\hline \multicolumn{9}{|c|}{ Semi-fine ceramics } \\
\hline 4 & 56 & 30 & 14 & - & 1.5 & 7 & 7 & Lutite-silt-arenite \\
\hline 6 & 57 & 30 & 13 & - & 2.0 & 8 & 5 & Lutite-silt-arenite \\
\hline 7 & 54 & 32 & 14 & - & 1.5 & 10 & 4 & Lutite-silt-arenite \\
\hline 8 & 56 & 32 & 12 & - & 1.5 & 8 & 4 & Lutite-silt-arenite \\
\hline 9 & 56 & 30 & 14 & - & 1.5 & 12 & 2 & Lutite-silt-arenite \\
\hline 10 & 58 & 32 & 10 & - & 2.2 & 7 & 3 & Lutite-silt-arenite \\
\hline 14 & 53 & 35 & 10 & 2 & 3.0 & 10 & 2 & Lutite-silt-arenite \\
\hline 16 & 56 & 30 & 14 & - & 1.9 & 9 & 5 & Lutite-silt-arenite \\
\hline 18 & 57 & 28 & 15 & - & 2.0 & 9 & 6 & Lutite-silt-arenite \\
\hline 20 & 60 & 30 & 10 & - & 1.5 & 8 & 2 & Lutite-silt-arenite \\
\hline 21 & 62 & 30 & 8 & - & 1.5 & 6 & 2 & Lutite-silt-arenite \\
\hline 22 & 58 & 30 & 12 & - & 1.0 & 9 & 3 & Lutite-silt-arenite \\
\hline 23 & 62 & 30 & 8 & - & 1.0 & 5 & 3 & Lutite-silt-arenite \\
\hline 24 & 58 & 30 & 12 & - & 2.0 & 9 & 3 & Lutite-silt-arenite \\
\hline 27 & 50 & 35 & 15 & - & 2.0 & 11 & 4 & Lutite-silt-arenite \\
\hline 28 & 58 & 32 & 10 & - & 1.0 & 10 & - & Lutite-silt-arenite \\
\hline \multicolumn{9}{|c|}{ Coarse ceramics } \\
\hline 1 & 55 & 29 & 12 & 4 & 2.5 & 8 & 8 & Lutite-silt-arenite \\
\hline 5 & 56 & 30 & 8 & 6 & 4.0 & 8 & 6 & Lutite-silt-arenite \\
\hline 11 & 52 & 30 & 18 & - & 2.5 & 6 & 12 & Lutite-silt-arenite \\
\hline 12 & 59 & 25 & 16 & - & 2.5 & 10 & 6 & Lutite-silt-arenite \\
\hline 13 & 58 & 22 & 20 & - & 1.5 & 16 & 4 & Lutite-silt-arenite \\
\hline 15 & 53 & 30 & 15 & 2 & 2.5 & 8 & 9 & Lutite-silt-arenite \\
\hline 17 & 55 & 25 & 20 & - & 2.0 & 5 & 15 & Lutite-silt-arenite \\
\hline 19 & 56 & 25 & 19 & - & 1.5 & 14 & 5 & Lutite-silt-arenite \\
\hline 25 & 56 & 26 & 13 & 5 & 3.0 & 10 & 8 & Lutite-silt-arenite \\
\hline 26 & 48 & 35 & 17 & - & 2.0 & 8 & 9 & Lutite-silt-arenite \\
\hline \multicolumn{9}{|c|}{ Very coarse ceramics } \\
\hline 2 & 50 & 24 & 18 & 8 & 5.0 & 26 & - & Lutite-silt-arenite \\
\hline 3 & 54 & 24 & 14 & 8 & 4.5 & 14 & 8 & Lutite-silt-arenite \\
\hline
\end{tabular}

(i.e., samples 2, 3). For these, the grain size distribution is lutite $50-54 \%$, silt $24 \%$, arenite $14-18 \%$, and rudite $8 \%$.

The structure of Palatca ceramics varies from lutitic-siltic (85-92\%), poorly arenitic (8-15\%), or compact, i.e., a sintered and partly vitrified matrix, depending on the firing temperature, for the semi-fine ceramics (Figs. 5, 6, and 7) to compact greywacke ${ }^{1}$ type (sintered, partly vitrified matrix) for the coarse and very coarse ceramics (Fig. 8). The latter categories consist of lutitic-siltic matrix embedding $8-20 \%$ arenitic grains and up to $8 \%$ gravel (rudite $<4 \mathrm{~mm} \varnothing$ ).

Matrix microstructure. Depending on the clay mineral composition and the firing temperature, the clayey matrix ${ }^{2}$ shows different degrees of thermal alteration, ranging from poorlysintered to complete vitrification processes. Consequently, four types of matrix microstructures have been classified based on the microcrystalline and amorphous phases derived from firing, i.e.:

o microcrystalline matrix: 1, 6, 8, 10, 14, 15 (Fig. 5);

o microcrystalline-amorphous matrix: $2,5,7,17,19$, 20, 22, 24 (Figs. 6, 7);

o amorphous-microcrystalline matrix: 4, 9, 11, 12, 13, 21, 23, 25, 26, 27 (Fig. 8);

o amorphous matrix: $3,16,18,28$.

\footnotetext{
${ }^{1}$ The term "greywacke" is used in sedimentary petrography to define sandstones with a matrix $>15 \%$ (Pettijohn et al., 1987).

${ }^{2}$ Here, "matrix" refers to homogeneous, compact (sintered \pm

vitrified) groundmass that embeds the unassimilated temper grains

$(>0.010-0.015 \mathrm{~mm})$, as visible under the microscope.
}

The fragments with microcrystalline matrix were probably fired at the lowest temperature, whereas samples with an amorphous matrix reached the highest temperatures.

The apparent porosity can be measured by using the method proposed by Shepard (1976) and applying the formula $\mathrm{Pa}$ $=(\mathrm{C}-\mathrm{A}) \rho_{\mathrm{aq} 35^{\circ} \mathrm{C}} * 100 /(\mathrm{A}-\mathrm{B}) \rho_{\mathrm{aq} 20^{\circ} \mathrm{C}}$, where $\mathrm{Pa}$ is the apparent porosity in $\%, \mathrm{~A}$ is the sample mass in air, $\mathrm{B}$ is the sample mass in water, $\mathrm{C}$ is the sample mass after being boiled in water, $\rho_{\mathrm{aq} 20^{\circ} \mathrm{C}}$ is the water density at $20^{\circ} \mathrm{C}\left(0.99823 \mathrm{~g} / \mathrm{cm}^{3}\right), \rho_{\text {aq } 35^{\circ} \mathrm{C}}$ is the water density at $35^{\circ} \mathrm{C}\left(0.99406 \mathrm{~g} / \mathrm{cm}^{3}\right)$. The apparent porosity is defined as the ratio between the volume of the open pores and the total volume of the fragment. The ceramics from Palatca are generally porous and the apparent porosity varies between 13 and $28 \%$ for semi-fine ceramics, 18 and $27 \%$ for coarse ceramics, and 31 and $35 \%$ for the very coarse ceramics (Table 2). The apparent porosity of a ceramic fragment is the sum of all the primary and secondary decomposition pores and the shrinkage cracks; it is a result of the firing temperature, the fineness of the ceramics, the mineralogy of the clayey raw materials, and on the modeling, drying, and firing technique.

The fairly large variation of apparent porosity of Palatca samples cannot be explained by the variation of the firing temperatures. However, the greater the number and size of the clasts is (e.g., very coarse pottery) the higher is the occurrence of contraction cracks. The apparent porosity is also enhanced when the primary pores change their orientation according to the outlines of the pebbles they mold. The factors that strongly influence apparent porosity are the prevalence of either kaolinite or illite, and their concentration vs. the amount of smectite and the drying technology that can influence the size of the primary pores.

Studia UBB Geologia, 2012, 57 (1), 13 - 21 


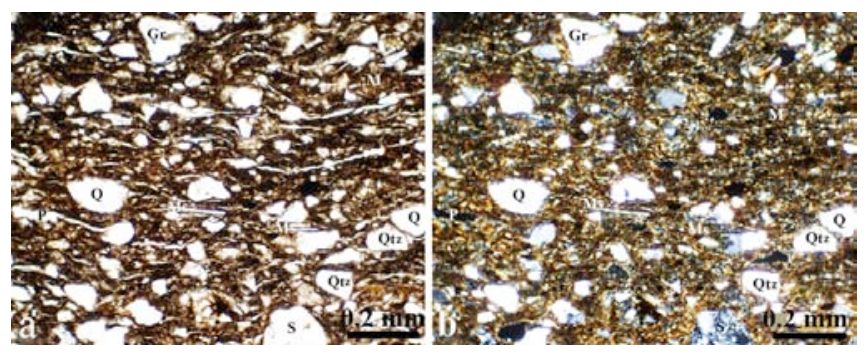

Fig. 5. Photomicrograph of a ceramic sample with microcrystalline matrix (M). Quartz (Q), muscovite (Ms), quartzite (Qtz), granite $(G r)$, silicolite $(S)$ and primary elongated pores $(P)$. (a) Plane-polarized light and (b) cross-polarized light (Sample 6).
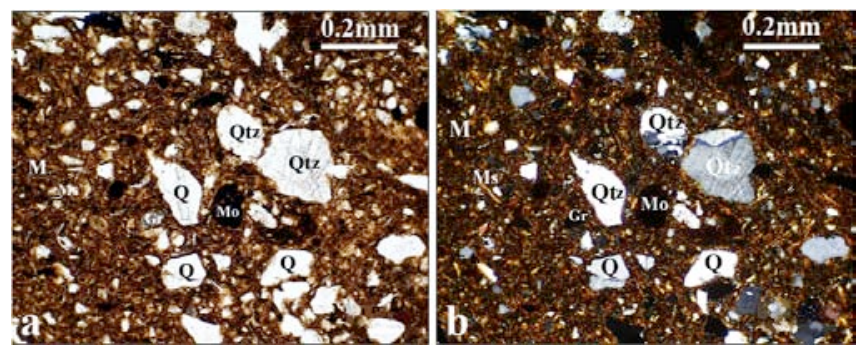

Fig. 6. Photomicrograph of a ceramics with microcrystallineamorphous matrix (M). Quartz (Q), muscovite (Ms), quartzite (Qtz), granite (Gr) and opaque minerals (Mo). (a) Plane-polarized light and (b) cross-polarized light (Sample 24).

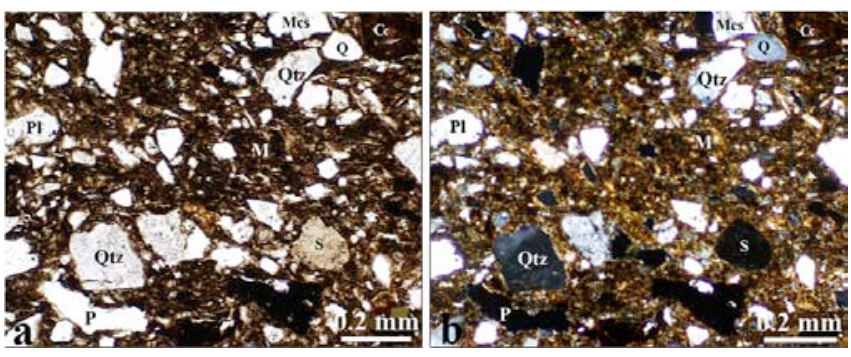

Fig. 7. Photomicrograph of a ceramic sample with microcrystalline-amorphous matrix $(M)$. Quartz (Q), quartzite (Qtz), micaschists (Mcs), ceramoclasts $(C c)$ and pores $(P)$. (a) Plane-polarized light and (b) cross-polarized light (Sample 7).

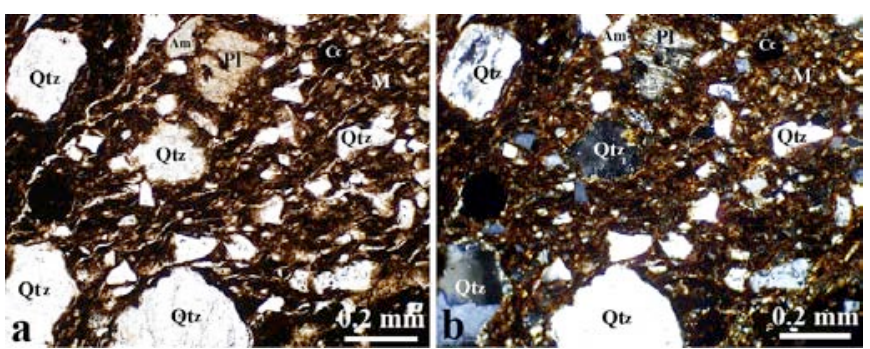

Fig. 8. Photomicrograph of a coarse ceramics with amorphousmicrocrystalline matrix (M). Plagioclase feldspars (Pl), quartzite (Qtz), amphiboles (Am), and ceramoclasts (Cc). (a) Plane-polarized light and (b) cross-polarized light (Sample 12).

Table 2. Apparent porosity of the Palatca ceramics.

\begin{tabular}{lclc}
\hline $\begin{array}{c}\text { Sample } \\
\text { No. }\end{array}$ & $\begin{array}{c}\text { Apparent } \\
\text { porosity }(\%)\end{array}$ & Ceramics fineness & Firing temperature \\
\hline 27 & $12.65^{*}$ & Semi-fine ceramics & $850-900^{\circ} \mathrm{C}$ \\
9 & $15.11^{*}$ & Semi-fine ceramics & $850-900^{\circ} \mathrm{C}$ \\
21 & 17.58 & Semi-fine ceramics & $850-900^{\circ} \mathrm{C}$ \\
6 & 18.82 & Semi-fine ceramics & $800-850^{\circ} \mathrm{C}$ \\
8 & 19.34 & Semi-fine ceramics & $800-850^{\circ} \mathrm{C}$ \\
14 & 19.41 & Semi-fine ceramics & $850^{\circ} \mathrm{C}$ \\
18 & 19.73 & Semi-fine ceramics & $900^{\circ} \mathrm{C}$ \\
10 & $21.8^{*}$ & Semi-fine ceramics & $850^{\circ} \mathrm{C}$ \\
23 & 21.13 & Semi-fine ceramics & $850^{\circ} \mathrm{C}$ \\
28 & 22.11 & Semi-fine ceramics & $900^{\circ} \mathrm{C}$ \\
24 & 22.75 & Semi-fine ceramics & $850^{\circ} \mathrm{C}$ \\
22 & 23.27 & Semi-fine ceramics & $850^{\circ} \mathrm{C}$ \\
7 & 23.31 & Semi-fine ceramics & $850^{\circ} \mathrm{C}$ \\
4 & 25.32 & Semi-fine ceramics & $850^{\circ} \mathrm{C}$ \\
16 & 28.42 & Semi-fine ceramics & $900^{\circ} \mathrm{C}$ \\
19 & 18.21 & Coarse ceramics & $850^{\circ} \mathrm{C}$ \\
26 & 19.35 & Coarse ceramics & $850-900^{\circ} \mathrm{C}$ \\
25 & 19.86 & Coarse ceramics & $850^{\circ} \mathrm{C}$ \\
17 & $22.01^{*}$ & Coarse ceramics & $850^{\circ} \mathrm{C}$ \\
13 & 23.53 & Coarse ceramics & $800-850^{\circ} \mathrm{C}$ \\
15 & 24.22 & Coarse ceramics & $800-850^{\circ} \mathrm{C}$ \\
12 & $24.60^{*}$ & Coarse ceramics & $900^{\circ} \mathrm{C}$ \\
5 & 25.51 & Coarse ceramics & $800-850^{\circ} \mathrm{C}$ \\
11 & $26.55^{*}$ & Coarse ceramics & $850^{\circ} \mathrm{C}$ \\
3 & 31.28 & Very coarse ceramics & $900-950^{\circ} \mathrm{C}$ \\
2 & 35.34 & Very coarse ceramics & $800-850^{\circ} \mathrm{C}$ \\
\hline & & &
\end{tabular}

The ceramics texture is defined by the orientation of the lamellar minerals (micas, illite) and the elongated primary pores. Textural features allow to distinguish between hand- and wheel-made ceramics. Most of our samples show a chaotic texture (i.e., 1-5, 7, 10, 13-17, 19-24, 28; Figs. 6, 7); rarely, an oriented one was noticed (i.e., 6, 8, 9, 11, 12, 18, 25-27; Figs. 5, 8). The apparent porosity varies between $12-35 \%$ (Tab. 2). The textural observations indicate that the Palatca ceramics were modeled by hand.

Studia UBB Geologia, 2012, 57 (1), 13 - 21

\section{Scanning electron microscopy study}

We used a fresh surface for the study of the ceramic body's microstructure. The BSE images (Figs. 9, 10) reveal the morphology of the clayish matrix following thermal transformations. Various clasts (e.g., quartz, feldspars and micas) as well as newly formed cracks and pores are visible in the matrix. An illustration is given by sample 4 (Fig. 10). Here, we notice the detachment of altered (illitized and smectitized) lamellae from the ends of the sintered clay 
aggregates. These argillization phenomena can be explained as follows: firing at around $800^{\circ} \mathrm{C}$, i.e., the temperature at which the second smectite de-hydroxilation stage was completed; at the same time, this temperature was below the one $\left(850\right.$ to $\left.900^{\circ} \mathrm{C}\right)$ at which illite and smectite structures collapse. Therefore, the processes of illitization and smectitization (namely by retrieval of clay minerals' structure by hydroxylation) could have occurred during the ceramics burial. Froh (2004) described similar features considering that in such cases the firing temperatures were less than $850^{\circ} \mathrm{C}$.

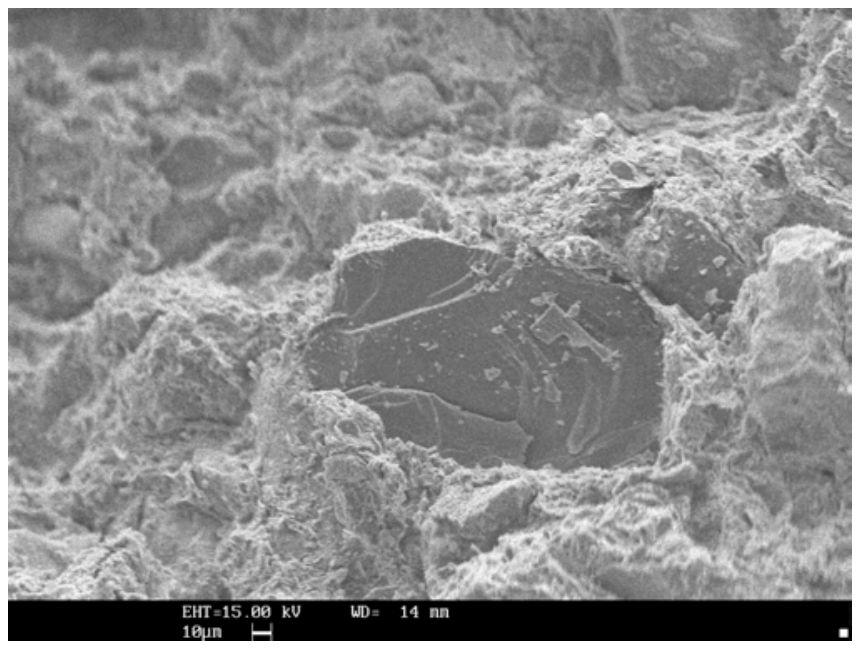

Fig. 9. Scanning electron micro-photograph of abundant clasts in the ceramic matrix. In the center, a feldspar crystalloclast can be observed (Sample 10).

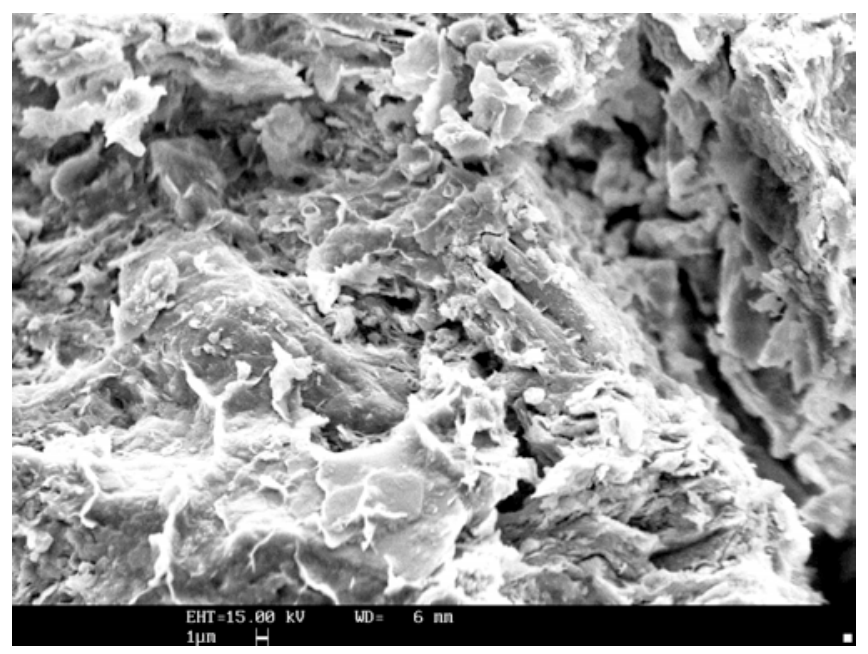

Fig. 10. Scanning electron micro-photograph of thermally transformed clay minerals. Lamellar endings of illite and illite/smectite are detached from the sintered clay aggregates (Sample 4).

The ceramic paste used for modeling the Palatca ceramics was obtained by homogeneously mixing siltic clay, temper, and water. The temper used for obtaining a proper plasticity of the mix consists of poorly sorted river sand (grain sizes from silt to gravel) and ceramoclasts (Tab. 1).

The simultaneous use of two temper types, i.e., sand and ceramoclasts is one of the main features of Palatca pottery. Just samples 2 and 28 , i.e., $7 \%$ of the analyzed samples do not contain ceramoclasts. However, in $75 \%$ of the samples sand is dominating over the ceramoclasts amount (Tab. 1).

River sand consists of lithoclasts and crystalloclasts. The petrography of the lithoclasts covers a relatively wide range of rocks, mainly of metamorphic origin (quartzites - commonly of heteroblastic type, micaceous quartzites, graphitic quartzites, gneiss, micaschist and quartzitic schist, sometimes mylonitized). The magmatic rocks are represented most frequently by granites, pegmatites, and subsequently granodiorites, but also by various types of dacites, rhyolites, and andesites with pyroxenes and amphiboles distinguished by the pilotaxitic or intersertal groundmass. The sedimentary rocks are micritic or sparitic limestones, sandy limestones, sandstones (usually with clayey-calcareous, and rarely with ferruginous cement), fine vitroclastic tuffs or tuffites, quartzitic-muscovitic silts, clayey silts, thermally transformed clays (hornfels), silicolites, and pedogenetic (soil) aggregates $(5,6,7,24,28)$ (Tab. 3; Figs. 5-8). Bioclasts were observed just in sample 2. Crystalloclasts are represented by quartz, plagioclases (all samples), orthoclase and microcline, muscovite and biotite - the latter is Fe-depleted in almost all samples. In addition, various heavy minerals were observed and are listed in the order of their frequency: garnet, epidotezoisite, tourmaline, zircon, just rarely pyroxene, hornblende, tremolite, apatite, monazite, titanite and glauconite (Tab. 4; Figs. 5-8). Calcite was identified in almost all samples, i.e., a primary calcite - with low transparency and birefringence when not fully thermally dissociated, related to the raw materials and a secondary one subsequently deposited in the pores and cracks during the ceramics burial in soil.

Ceramoclasts are angular fragments obtained by crushing older waste ceramics. With respect to their composition, they are similar to the investigated ceramics. Some modifications in the appearance may occur as the consequence of different firing temperatures of the ceramoclast and the host ceramics (Figs. 7, 8).

The clayey raw material used for obtaining the Palatca pottery is compositionally distinctive in individual samples. Nevertheless, it displays an overall siltic polymictic character and a low-calcite content. Sample 8 that was fired at the lowest temperature contains microcrystalline, thermally not transformed calcite scattered in the matrix. Most samples contain kaolinite or illite-dominated clay with variable amounts of smectite.

\section{X-Ray diffraction analysis}

The XRD powder patterns display the characteristic results of crystalline phases typically present in such ceramics. Thus, we detected relict minerals that were not irreversibly transformed. These are minerals whose structures collapsed (i.e., particularly clay minerals) as well as newly formed hightemperature crystalline phases or tracers of amorphization vitrification processes during firing. We illustrate our findings in 10 diffractograms ranked according to the composition of the clayey raw material. The maximum kaolinite content (sample 18) gradually decreases from top to bottom with the simultaneous increase of illite and mica (Fig. 11).

We have identified the following relict minerals: quartz (full range XRD pattern), feldspar (only the most intense peaks), de-structured illite and illitized micas (highlighted by $00 \ell$ lines, whose intensity decreases as the firing temperature increases; such peaks may even disappear, e.g., in samples 3,18 ) if the mica content is low. The lines' intensity depends on both temperature and amount of 2:1 type phyllosilicates (e.g., sample 2 contains very small amounts of mica and illite). 
Table 3. Petrography of the lithoclasts from Palatca ceramics.

\begin{tabular}{|c|c|c|c|c|c|c|c|c|c|c|c|c|c|c|c|c|c|c|c|}
\hline \multirow[b]{3}{*}{ 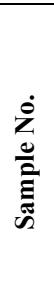 } & \multicolumn{19}{|c|}{ Rock type } \\
\hline & \multicolumn{6}{|c|}{ Metamorphic } & \multicolumn{6}{|c|}{ Igneous } & \multicolumn{7}{|c|}{ Sedimentary } \\
\hline & 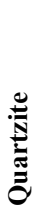 & 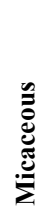 & U气 & 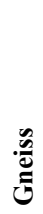 & 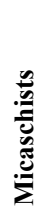 & 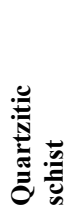 & 节 & 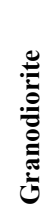 & 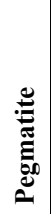 & 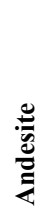 & $\begin{array}{l}\stackrel{\mathscr{E}}{\mathscr{E}} \\
\text { D }\end{array}$ & 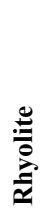 & 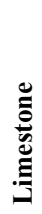 & 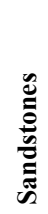 & 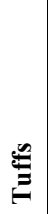 & 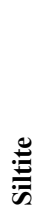 & 兄 & 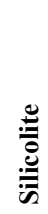 & 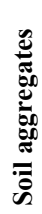 \\
\hline 1 & + & & & + & & & + & & & & & & & + & & & & & \\
\hline 2 & + & + & & & + & & & & & + & & & + & & & & & & \\
\hline 3 & + & & & + & & & & & + & + & & & & + & & + & & & \\
\hline 4 & + & & & & + & & + & & & + & & & + & & & & + & & \\
\hline 5 & + & & & + & & & & & & & & & & & & & & & + \\
\hline 6 & + & & & + & 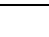 & & & & & & & + & & & & & & & + \\
\hline 7 & + & & & + & + & & & & & & & + & & & & & & + & \\
\hline 8 & + & & & + & & & & & & & & & & & & & & & + \\
\hline 9 & + & + & & & & & + & & & & & & & & & & & & \\
\hline 10 & + & + & & + & & & & & & & & & & & + & + & & & \\
\hline 11 & + & & & & & + & & & & & & + & & & & & & & \\
\hline 12 & + & & & & & & + & & & + & & + & & 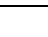 & & + & + & & \\
\hline 13 & + & & & & & + & + & + & & + & & + & & + & & & & + & \\
\hline 14 & + & & & & & & & & & + & + & & & & + & & & & \\
\hline 15 & + & & & + & & + & & & & & & & & & + & & & + & \\
\hline 16 & + & & + & & & + & + & & & & & & & & & + & & + & \\
\hline 17 & + & & & + & & & & & & & & & & & & & & + & \\
\hline 18 & + & & & & & & + & & & + & & & + & & & & & & \\
\hline 19 & + & & + & + & & + & & + & & & & & & & & & & & \\
\hline 20 & + & & & + & + & & & & & & & & + & & & & & & + \\
\hline 21 & + & & & & & + & & & & & & & & & & & & & \\
\hline 22 & + & & + & + & + & & & & & + & & & & & & & & & \\
\hline 23 & + & & & + & & & & & & & & & & & & & & + & \\
\hline 24 & + & + & & + & & & & & & & & & & & & & & & + \\
\hline 25 & + & & + & + & + & & & & $\begin{array}{lll}+ & & \end{array}$ & & & & & + & & & & & \\
\hline 26 & + & & & + & & & & & & & & & & + & & & & & \\
\hline 27 & + & & & + & & & & & & & & + & + & & & & & & \\
\hline 28 & + & & & + & & & & & & & & & & & + & & & & + \\
\hline
\end{tabular}

Table 4. Mineralogy of crystalloclasts from Palatca ceramics.

\begin{tabular}{|c|c|c|c|c|c|c|c|c|c|c|c|c|c|c|c|c|c|c|c|c|}
\hline \multirow[b]{3}{*}{ 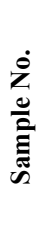 } & \multicolumn{20}{|c|}{ Minerals } \\
\hline & & & & & & & & & & & & & & & & & & & & \\
\hline & 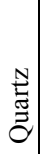 & $\begin{array}{l}0 \\
0 \\
\frac{\pi}{0} \\
\frac{0}{00} \\
\frac{\pi}{2}\end{array}$ & 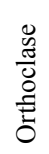 & 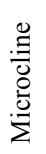 & 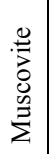 & $\begin{array}{l}.0 \\
.00 \\
.00 \\
0\end{array}$ & 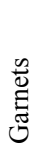 & 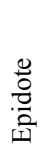 & 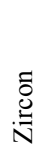 & $\begin{array}{l}\text { 号 } \\
\text { 泀 } \\
\text { 。 }\end{array}$ & 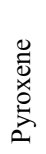 & 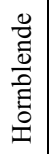 & 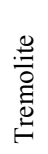 & $\begin{array}{l}\text { 号 } \\
\text { 苞 }\end{array}$ & 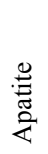 & $\begin{array}{l}\stackrel{\mathscr{N}}{N} \\
\overparen{\Xi} \\
\Sigma \\
\Sigma\end{array}$ & 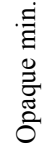 & 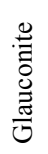 & 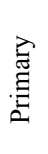 & $\begin{array}{l}\vec{E} \\
\bar{E} \\
\overline{0} \\
\tilde{D} \\
\tilde{n}\end{array}$ \\
\hline 1 & + & + & + & + & + & + & & + & & & & + & & & & + & & & & \\
\hline 2 & + & + & & & + & + & + & + & + & & & & & & & & & & + & \\
\hline 3 & + & + & & + & + & + & & & & + & & & & & & & & & & \\
\hline 4 & + & + & + & & + & + & + & & & & & & & & & & & & + & \\
\hline 5 & + & + & & + & + & + & & + & & & & & + & & & & & & & \\
\hline 6 & + & + & + & + & + & + & + & & + & & & & & & & & + & & & \\
\hline 7 & + & + & + & & + & + & & & & & & & & & & & & & & \\
\hline 8 & + & + & & + & & & + & + & + & + & & & & & & & & & + & \\
\hline 9 & + & + & + & & & & & & & & & & & & + & & & & & + \\
\hline 10 & + & + & + & + & + & + & + & + & & + & & & & & & & & & + & + \\
\hline 11 & + & + & & & + & + & & & & & & & & & & & & & + & + \\
\hline 12 & + & + & & + & + & + & & & + & & & & & & & & & & & + \\
\hline 13 & + & + & + & & + & + & + & + & & + & & & & & & & & & & \\
\hline 14 & + & + & & & + & + & & & . & & + & & & + & & & & & + & \\
\hline 15 & + & + & + & & + & + & + & + & + & + & & & & & & & & & & \\
\hline 16 & + & + & + & & & & & & & & & + & & + & & & + & & & \\
\hline 17 & + & + & + & & + & + & + & + & & & & & & & & & & & & + \\
\hline 18 & + & + & + & & + & & & & & & & & & & & & & & + & + \\
\hline 19 & + & + & + & + & + & + & + & & & & + & & & & & & & & & \\
\hline 20 & + & + & + & & + & + & & & & & & & & & & & & & + & + \\
\hline 21 & + & + & & & + & + & + & & + & & & & & & & & & & & \\
\hline 22 & + & + & & & + & + & & & & + & & & & & & & + & & & \\
\hline 23 & + & + & & & + & + & & & & & & & & & & & & & & \\
\hline 24 & + & + & & & & & + & & & & & & & & & & & + & & \\
\hline 25 & + & + & & + & + & + & + & & & + & & & & & & & & & & \\
\hline 26 & + & + & + & & + & + & & & & & & & & + & & & + & & + & \\
\hline 27 & + & + & & & + & & + & & & & & & & & & & & & + & + \\
\hline 28 & + & + & + & & + & + & + & & & & & & & & + & & & & & \\
\hline
\end{tabular}


The increasing compaction of ceramics during firing is correlated with the degree of de-structuring (sintering) and the structural collapse or solid phase reactions leading to vitrification or to the formation of new crystallized phases. All these processes affect the clay minerals. Kaolinite collapses at the lowest temperature (below $700^{\circ} \mathrm{C}$ ). Consequently, even if kaolinite is not detected, all samples show the formation of an amorphous mass indicated by a bulge in the XRD profile at about $7 \AA$ (see Fig. 11) and caused by the collapsing process. After the structural change at $280-300^{\circ} \mathrm{C}$, smectites start to behave similarly to illite, i.e., the smectitic structure looses its ionic exchange properties. The breakdown of illite and smectite continues until $850^{\circ} \mathrm{C}$, while the complete collapse occurs above this temperature. These changes are marked by lower intensities for the $00 \ell[\mathrm{d}(001) \approx 10 \AA, \mathrm{d}(002) \approx 5 \AA, \mathrm{d}(003) \approx 3.3 \AA$ - the latter overlapping the quartz line, and $\mathrm{d}(005) \approx 2 \AA$ ] lines, and sometimes to their disappearance in the case of mica-free samples. The $\mathrm{d} \approx 4.5 \AA$ and $2.5-2.6 \AA$ lines, corresponding to $2: 1$ type clay minerals persist also after the structural collapse (e.g., samples 3 or 16, the line labeled with $\mathrm{m}$ ). If mica is present with illite, the previously mentioned lines disappear completely just above $1000^{\circ} \mathrm{C}$, i.e., when the muscovite structure collapses. We established three relevant temperature intervals for Palatca ceramics.

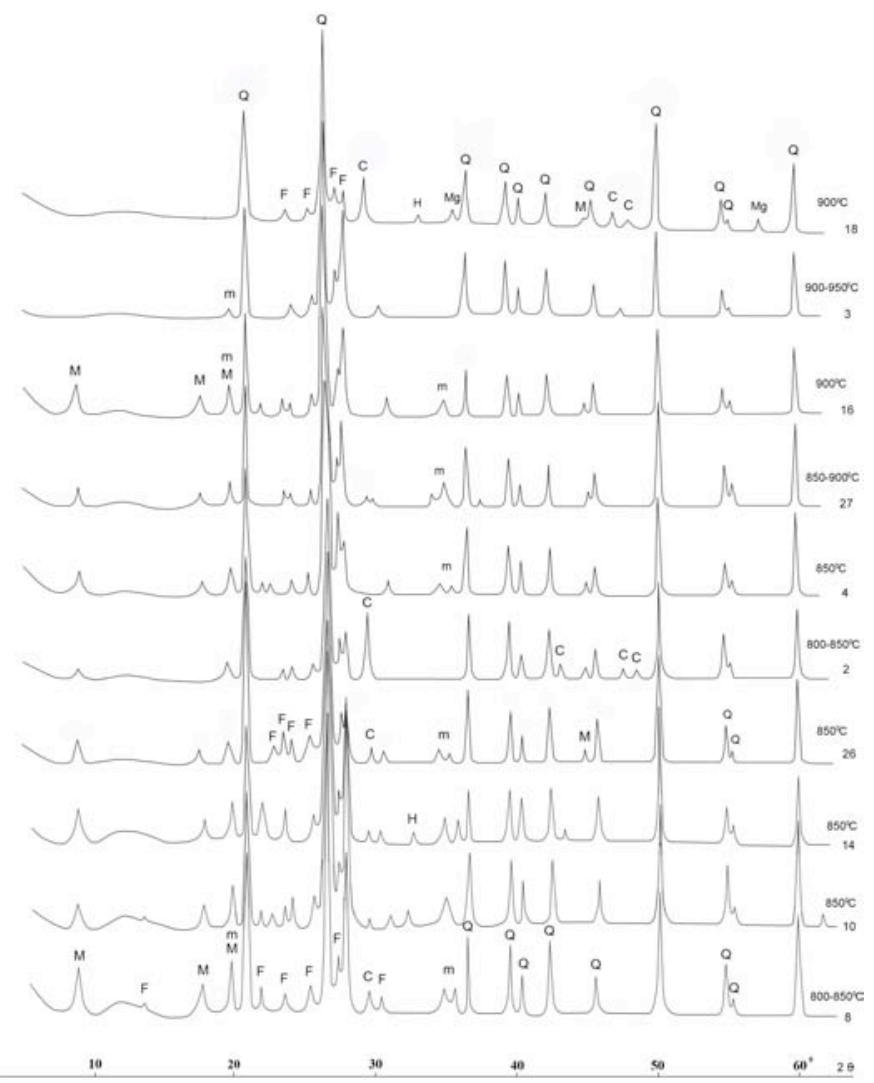

Fig. 11. Representative $X R D$ patterns for Palatca ceramics fired in the interval $800-950^{\circ} \mathrm{C} . Q-$-quartz, F-feldspar, $M$ - muscovite-illite, $C$-calcite, $M g$ - magnetite or/and maghemite, $H$-hematite, $m-2: 1$ type clay minerals, partly collapsed.

They are based on the decrease (sample 2) or the disappearance (samples 3, 8) of the above-listed lines along with the occurrence of newly formed minerals, and also on our microscopic observations:

$-800-<850^{\circ} \mathrm{C}(2,8$, and samples that were not included in Fig. 11 , i.e., 1, 5, 6, 13, 15). This group represents $25 \%$ of the total number of samples;
- $850-900^{\circ} \mathrm{C}(4,10,14,16,18,26,27$, and samples that were not included in Fig. 11, such as 7, 9, 11, 12, 17, 19-24, 25, 28). This group represents $71 \%$ of the total number of samples;

- $>900-950^{\circ} \mathrm{C}$ (3; only one sample was fired over $900^{\circ} \mathrm{C}$ ). The only sample in this group represents $4 \%$ of the total samples.

The newly formed phases during firing are amorphous masses that resulted from the breakdown of clay minerals, calcium or alkaline glass, possibly K-feldspar, magnetite and/or maghemite (18) and hematite $(14,18)$.

Samples 2, 8, 10, 14, 18, 26, and 27 contain calcite. Based on our microscopic observations, we can state that thermally affected calcite is of primary origin in samples $2,8,14$, and 26. In contrast, calcite is of mainly secondary origin in samples 10,18 , and 27 . The ceramic walls of sample 18 display a $0.2-\mathrm{mm}$ thick deposit of thermally unaffected calcite that may originate from a painting layer.

\section{Thermal transformations}

Our XRD data and microscopic study reveal numerous physical and chemical effects caused by increasing temperature during firing. These effects are (i) the formation of primary pores and contraction cracks at the border between large clasts and the matrix (Figs. 5, 7, 8 ) and (ii) the breakdown the clay minerals evidenced by the diminishing of the matrix birefringence and the intensity decrease or disappearance of certain diffraction lines (see matrix microstructure description and Fig. 11). Further, (iii) the partial or total decomposition of calcite with diminishing of the transparency and birefringence of the crystalline aggregates; reaction between $\mathrm{CaO}$ and the clayey matrix, with the formation of glassy films; and (iv) the formation of reaction products at the boundary between quartz and the clayey matrix. Finally, (v) the alkaline ion (especially K) mobilization that leads to the formation of glass; in a more advanced stage, the generation of neoformed K-feldspar (sample 3; Fig. 11); and (vi) the formation of hematite on iron oxy-hydroxides and its partial or total transformation into maghemite, or into magnetite under reducing conditions (18; Fig. 11).

\section{Location of the raw material}

The temper. The ceramics lithic components used as temper provide the most relevant petrographical data in the view of identifying the source of the raw materials. Here, the temper is represented by river sand that was undoubtedly mined from the alluvia of Someşul Mic River, in the proximity of the potter's workshop. This is supported by the petrographical and mineralogical results and the relative abundance of the rocks constituting the temper material. The composition, grain-size distribution and grain morphology plead for hard rocks cropping out at significant distances from the alluvial deposits that they have generated. The characteristics of the Someşul Mic River basin fit the association of rocks and minerals that we have identified in the Palatca ceramics (Tabs 3,4). Most of the fragments may originate from the gneisses, granites and pegmatites of the Bihor Unit. We may also assume that the andesites, dacites, and partially the rhyolites found in the ceramics most likely belonged to the Late Cretaceous - Paleocene (banatitic) volcanic unit that outcrops along the Someşul Rece River and some of the Someşul Mic tributaries (Ianovici et al., 1976). The geochemistry of the Palatca samples discussed in 
(Hoeck et al., 2009) could better sustain the temper origin from the Someşul Mic alluviums than from the Sarmatian sedimentary deposits.

The clayey raw material. Most of the Badenian and Sarmatian clays and calcareous clays, including those occurring around the Palatca site, show a polymictic character. Their associated clay mineral fraction predominantly consists of illite, subordinately of kaolinite (in almost constant amounts), and smectite (showing significant quantitative variations, up to becoming the dominant component of the clay - in this case defined thus as bentonite) (Ghergari et al., 1985, 1990; Mészáros et al., 1992a, b; Ghergari, unpubl. data). Based on the results of this study and especially on their behavior during firing, the mineral composition of the clays is polymictic, dominated by illite and kaolinite, with subordinate smectite. The illitekaolinite ratio varies from an illitic- to a kaoliniticdominated clay, depending on the particular quarry that was mined in each case. Accordingly, we presume that the raw clayey material is represented by alluvial clay or by a local Badenian or Sarmatian clay accumulation with illitickaolinitic composition. In the latter case, the clay must have been located on the top of a tuff level (possibly the BorşaApahida tuff, according to the features of the lithoclasts; Ghergari et al., 1991) and it was contaminated with soil.

The Late Bronze Age ceramic workshop was most likely located near the Someşul Mic River bank, west or northwest of the Palatca site in the area of Gădălin, Sic, or the Silivaş villages.

\section{SUMMARY AND CONCLUSIONS}

The ceramic samples from Palatca (Cluj) can be classified as semi-fine ( $57 \%$ of the total, thus dominant), coarse $(36 \%)$ and very coarse $(7 \%)$.

The fabric of the Palatca ceramics varies from slightly arenitic, lutitic-siltic, with sintered and partially vitrified matrix (depending on the firing temperature) in the case of the semi-fine ceramics, to compact greywacke type (with sintered and partially vitrified matrix) in the case of the coarse and very coarse ceramics. The matrix microstructure varies from microcrystalline to amorphous, as controlled by the firing temperatures and the mineralogical composition of the ceramic paste.

Typically, the texture is chaotic or rarely oriented. This is characteristic for hand-made ceramics. The apparent porosity, defined by the total amount of open pores (primary, secondary, and contraction fissures) varies from $13 \%$ to $35 \%$.

The clayey matrix (sintered and vitrified) embeds the temper grains represented by unsorted river sand (consisting of lithoclasts and crystalloclasts) and ceramoclasts; this represents a typical feature of the Palatca pottery.

The variations in fineness, porosity, ceramics fabric, durability and compactness degree may be correlated with differences concerning the raw materials composition and preparation, as well as the firing technologies used.

Based on microscopic and XRD results, we estimate that firing temperatures were in the range of 800 to $950^{\circ} \mathrm{C}$; nevertheless, most of the samples $(71 \%)$ have been fired at temperatures between 850 and $900^{\circ} \mathrm{C}$.

The microscopic features of the matrix, supported by XRD and SEM observations reveal the use of a poorly sorted siltic and carbonatic polymictic clay (mainly a mixture of illite, kaolinite, and smectite) originating from either the Badenian and Sarmatian deposits, or from alluvial clay lenses as clayey raw material. These deposits crop out along the right banks of the Someşul Mic River, west and northwest of the Palatca site.

The petrographic composition of the lithoclasts and crystalloclasts constituting the unsorted river sand used as temper material indicates a remote location for the hard rock sources. The high frequency of gneisses, granites and pegmatites point to the Bihor Unit in the Gilău Mountains as source, and the rocks being transported by the Someş River.

Illitization, smectitization, and the formation of secondary calcite are observed alteration phenomena that occurred within the soil in some of the samples that were fired at low temperatures.

Acknowledgments. The samples for this study were provided courtesy of Dr. Mihai Rotea from the National History Museum of Cluj-Napoca. We are grateful to Mag. Dr. Gertude Friedl from Salzburg University (Austria) for facilitating the investigations in the Scanning Electron Microscopy laboratory, performed in the framework of CEEPUS program. Thanks are due to Prof. dr. Corina Ionescu for guidance and access to analytical facilities provided during CS's doctoral studies. The present study was financially supported by UEFISCSU/CNCSIS PNII2241/2008 Project.

\section{R E F E R E N C E S}

Froh, J. 2004, Archaeological ceramics studied by scanning electron microscopy. Hyperfine Interactions, 154 (1-4): 159-176. http://dx.doi.org/10.1023/B:HYPE.0000032074.98045.cc

Filipescu, S. 1996, Stratigraphy of the Neogene from western border of the Transylvanian Basin. Studia UBB Geologia, 41 (2): 3-78.

Ghergari, L., Petrescu, I. \& Simuț, D. 1985, Aprecieri paleoclimatice şi paleogeografice asupra sarmaţianului de la Aştileu (Oradea), pe baza studiului mineralelor argiloase (notă preliminară). Crisia, XV: 467-471.

Ghergari, L., Hosu, A. \& Ivan, I. 1990, Mineralogical composition of the lower Badenian sediments al Lăpugiu de Sus (Hunedoara county) - paleoenvironment indicator. Studia UBB Geologia-Geographia, XXXV (2): 23-32.

Ghergari, L., Meszáros, N., Mârza, I., Chira, C., Filipescu, S. \& Ivan, I. 1991, Contributions to the petrographic and chronostratigraphic knowledge of the tuffs in the Cojocna area. In Geological formations of Transylvania, Romania. The volcanic tuffs from the Transylvanian Basin, Romania (Mârza, I, Ed.), Cluj-Napoca, vol. 3, 207-216.

Ghergari, L., Lazarovici, G., Ionescu, C. \& Tămaş, T. 1999, Studii geoarheologice asupra unor artefacte ceramice din Neoliticul Timpuriu din România: Staţiunea de la Lunca - Poiana Slatinii, județul Neamț. Angustia, 4: 1-7.

Ghergari, L., Țentea, O. \& Marcu, F. 2000, Aspectele mineralogice ale ceramicii lucrate cu mâna din castrul roman de la Gilău. Acta Musei Apulensis, 37 (1): 401-416.

Hoeck, V., Ionescu, C., Ghergari, L. \& Precup, C. 2009, Towards mineralogical and geochemical reference 
groups for some Bronze Age ceramics from Transylvania (Romania). Studia UBB Geologia, 54 (2): 41-51. http://dx.doi.org/10.5038/1937-8602.54.2.8

Ianovici, V., Borcoş, M., Bleahu, M., Patrulius, D., Lupu, M., Dimitrescu, R. \& Savu, H. 1976, Geologia Munţilor Apuseni. Ed. Acad. RSR, Bucureşti, 631 p.

Ionescu, C., Ghergari, L. 2002, Modeling and firing technology - reflected in the textural features and mineralogy of the ceramics from Neolithic sites in Transylvania (Romania). Geologica Carpathica, 53 (Spec. Iss. on CD).

Ionescu, C., Ghergari, L. 2007, Mineralogical and petrographic features of the Roman ceramics from Napoca. In Ceramica romana din Napoca (Rusu-Bolindet, V., Ed.), Biblioteca Mvsei Napocensis, XXV: 434-462.

Jánai, A., Kozák, M. \& Rózsa, P. 1997, Comparison of the methods of rock-microscopic grain-size determination and quantitative analysis. Mathematical Geology, 29 (8): 977-991. http://dx.doi.org/10.1023/A:1022305518696

Maggetti, M. 2006, Archaeometry quo vadis? In Geomaterials in cultural heritage (Maggetti, M., Messiga, B., Eds.). Geological Society of London Special Publication, 257: 1-8.

Marinescu, F., Peltz, S. 1967, Geological map of Romania. Scale 1:200.000, Bistrița Sheet. Geological Institute of Romania, Bucharest.

Moody, J., Robinson, H.L., Francis, F., Nixon, L. \& Wilson, L. 2003, Ceramic fabric analysis and survey archaeology: The Sphakia survey. The Annual of the British School at Athens, 98: 37-105.

Mészáros, N., Ghergari, L. \& Strusievicz, E. 1992a, Contributions to the knowledge of the lithology and stratigraphy of the Miocene deposits from the Ocna Mureş zone (Transylvanian Basin). Studia UBB GeologiaGeographia, XXXVII (2): 64-70.

Mészáros, N., Ghergari, L. \& Chira, C. 1992b, The Badenian deposits at Borzeşti. Studia UBB Geologia-Geographia, XXXVII (2): 71-78.

Pettijohn, F.J., Potter, P.E. \& Siever, R. 1987, Sand and sandstone $\left(2^{\text {nd }}\right.$ ed.). Springer Verlag, New York, $553 \mathrm{p.}$ http://dx.doi.org/10.1007/978-1-4612-1066-5

Precup, C. 2008. Bronze Age ceramics from Transylvania: mineralogical and technological features. Unpublished PhD Thesis, Babes-Bolyai University, Cluj-Napoca, 189 p. (in Romanian).

Rapp, G., Hill, C.L. 1998, Geoarchaeology. The earthscience approach to archaeological interpretation. Yale University Press, New Haven, 274 p.

Rotea, M. 1997, Archaeological research at Palatca „Togul lui Mândruşcă", preliminary observations. Revista Bistritei, X-XI: 13-19 (in Romanian).

Saulea, L., Dumitrescu, I., Bombiță, G.H., Marinescu, F., Borcoş, M. \& Stanca, J. 1968, Geological map of Romania. Scale 1:200.000, Cluj Sheet. Geological Institute of Romania, Bucharest.

Shepard, O.A. 1976, Ceramics of the archaeologist $\left(9^{\text {th }}\right.$ ed.). Carnegie Institute of Washington, USA, $414 \mathrm{p}$.

Tite, M.S. 1992, The impact of electron microscopy on ceramic studies. Proceedings of the British Academy, 77, Oxford University Press, London, p. 111-131.

Wentworth, C.K. 1922, A scale of grade and class terms for clastic sediments. Journal of Geology, 30: 377-392. http://dx.doi.org/10.1086/622910 